\title{
Traditions in vocational education of future teachers at the university
}

\author{
Marina Ivanovna Aldoshina ${ }^{1}$ \\ Orel State University named after I.S. Turgenev, Center for Interaction with the Russian Academy of \\ Education, Orel, Russia
}

\begin{abstract}
The modern sociocultural situation actualizes the issue of the role and place of tradition as a criterion for the preservation and transmission of historical experience and the basis of the civic identity of society and the ethnic identity of an individual in vocational education in Russia. Russia's entry into the world educational space, modernization of Russian education based on the competence-based approach, developed with due account for the general trends in the education development in European countries, involves not only updating the content and technologies of education. The subprogram "Vocational Education Development" of the State Program of the Russian Federation "Education Development" for the period of 2013-2020 has the purpose of increasing the contribution of vocational education to the socio-economic and cultural modernization of Russia, to increasing its global competitiveness, ensuring the demand for each student in the economy and society. Therefore, among the priority tasks of higher education is to improve the quality of training future teachers for the Russian education system at different levels, to form their readiness for pedagogical activity in modern conditions. The purpose of this article is to determine the significance of the historical and sociocultural tradition for vocational education at Russian universities by using the comparative analysis of historical-pedagogical, regulatory-legal and methodological sources. The author traces the possibilities of the impact of the university stage of education on the process of ethnocultural development and ethnic identification of a modern student in university vocational pedagogical education. The fundamental novelty of formulation and ways of solving the issue in this article is determined by taking into account the specifics of the digitalization stage in modern education and the features of university education technologies and techniques during the period of overcoming the consequences of the coronavirus epidemic.
\end{abstract}

Keywords: historical experience, university education, culture, ethnocultural development

\section{Introduction}

The modern world is characterized in its development by the trend of globalization,

${ }^{1}$ Corresponding author: maraldo57@mail.ru 
increased uniformity and generalization. In the field of education, in this regard, the issue of preserving spiritual bonds, foundations, the mental structure of personality and ethnoculture of each individual nation becomes topical. This issue is actualized in many turning periods of world history, but traditionally manifests itself at the turn of centuries and millennia. By the second quarter of the $21^{\text {st }}$ century, it becomes necessary to understand the relationship between tradition and innovation [1] in a modern technologized digital society, even more united in its expectations during the coronavirus epidemic. The pandemic and the spread of information and communication technologies for the transfer of information and education have actualized the importance of social-informational competence, which "includes the acquisition, processing, issuance of information, its transformation, the use of mass media technologies, computer literacy, ability to use the Internet and electronic technologies" [2, 3]. Obviously, young people cannot live and learn without gadgets and the Internet that nowadays penetrate all spheres of human life, and governing bodies "strongly encourage the use of digital technologies for effective student practice" [4, 5], confirming the "impact of digital technologies on students' competitiveness and vocational education in economically developed countries" [6]. A particular problem is historical unconsciousness, lack of spiritual guidance among young people, loss of a sense of rootedness and historical continuity [7]. At a speech to legislators on April 24, 2019, the President of the Russian Federation V.V. Putin said: "It is clear that we must pay the necessary attention to physics and mathematics, other natural sciences. But what creates our identity must not be completely forgotten. In case of failure to do this, all our achievements, even in the economic sphere, will come to nothing".

\section{Methods}

The main research method is a comparative analysis and questioning of students and university teachers on the importance of traditions and ethnocultural education in vocational pedagogical education at the university.

Traditions are a significant mechanism of pedagogical education, since they are the basis of education and the mechanism for the transmission of socio-cultural experience, a significant method of personality formation and education, as well as the basis of distinctive conservatism of education, a counterbalance to the innovative development vector, the basis and measure of the quality of education and culture. The traditionalist understanding of education, still enshrined in the main regulatory legal acts of the Russian statehood, involves its consideration not only as a combination of the level of training and development, but also the manners, which presupposes the internal painstaking self-construction work, the sum of labor capacities (those of teachers, the family, the student him/herself), striving for the personality as a certain height of spiritual, uncreated development (M.I. Aldoshina, N.A. Astashova, B.M. Bim-Bad, M.V. Boguslavsky, O.V. Dolzhenko, D.A. Endovitsky, A.S. Zapesotsky, etc.) [8]. The national idea determined the popular and humanistic nature of Russian education. Ravkin wrote as follows: "The concept of the Russian national idea is very broad, it is a part of both national and universal human culture ... First of all, the idea of rapprochement of peoples, national cultures based on respect for their historical national and universal values" [9]. In what form do ethnocultural traditions form the basis of the national idea? In general terms, the answer to this question can be correlated with the triad of citizenship traditions as interpreted by Shevelev, who actualizes "taking into account civic education traditions that have developed in national pedagogy, the emphasis on the study and interpretation of the value system of today's youth in Russia as a key characteristic and preconditions of strategies for 
effective civic education and the need for harmony in the social environment and pedagogical tools used by modern education" [10].

\section{$3 \quad$ Results}

The significant role of ethnoculture in the formation of an individual and a professional is not automatically actualized, but implemented in education.

To confirm the author's ideas at Russian universities (Orel State University named after I.S. Turgenev, Kursk State University, Northern (Arctic) Federal University named after M.V. Lomonosov, Ryazan State University named after S.A. Yesenin and Kuban State University) implementing educational professional-pedagogical programs in the field of study 44.03.01 and 44.03.05 Pedagogical Education, a questionnaire survey of future teachers was carried out in order to identify the attitude to traditions and factors of the ethnocultural development of a future teacher.

The data of this study show students' positive attitude towards various aspects of ethnocultural education and the formation of ethnic identification of a person at the university. Statistically significant differences in the effectiveness of ethnocultural development of university students in the experimental and control groups were found for ten indicators out of twelve. As for the indicators "Active immersion in the ethnocultural environment" and "Individual style of ethnocultural activity, the large statistical significance of differences is not indicative of their productivity. Successful formation of such indicators as "Personal position" and "Students' creative potential in ethnocultural activity" is a sufficient factor, indicating activity effectiveness. The most important result of the study was high levels of differences (up to 6\%) in terms of the indicators "Significance of emotional-sensory response" and "Active development of phenomena and works of Russian ethnic culture", which confirms "the importance of formed ethno-aesthetic culture and ... ethnic identification in characterizing the personality of a student studying at a classical university" [8]. An even greater significance of differences (from 1 to 5\%) was demonstrated by the indicators "The need for the purposefulness of the process of forming the ethno-aesthetic culture of students", "Formation of value-based orientations to the creative use of artifacts and knowledge about the phenomena and works of the native culture in professional activity and behavior", "Formation of an individual communication style, activity and behavior".

The results obtained allow concluding that there is a need for purposeful activity on the ethnocultural development of university students in the educational process. The practical experience of a university teacher allows highlighting the stages of organizing the purposeful formation of ethnic identity of future teachers. "Identity formation is a constant process that continues throughout a person's life ... the formation processes are rapid, and violations leave an imprint on all subsequent personality development" [11], "is formed through the emergence and resolution of intrapersonal conflicts" [12].

The adaptation stage (first year of study) aims to adapt students' personality to university education. At this stage, they study psychological and pedagogical disciplines, implement various types of research work with a complex of adaptive episodic and non-scale educational affairs.

The manifestation stage (second year of study) aims at the formation of the basis of humanistic value orientations in vocational pedagogical activity through an elaborate system of skills competitions and the identification of areas of expertise.

The actualization stage (third year of study) is focused on the manifestation of professional axiosphere of a future teacher in specific types of vocational pedagogical 
activities through the implementation of systematic activities in pedagogical practices, skills quests and competitions with the involvement of working teachers, at training and studio classes.

The individualization stage (fourth year of study) is carried out after the first experience of practical activity, when a set of professional values and value orientations in pedagogical activity is adjusted. This stage ends with self-assessment and reflection.

\section{Conclusion}

Vocational education at the university consists of four years of training for future professional activities. This period is characterized by the formation of student's worldview frame, the rethinking of life views and beliefs, the development of personal qualities, attitudes and values, their refraction in the professional sphere. The empirical and theoretical results of understanding the place and significance of the role of ethnoculture-oriented educational activity in university education of future teachers indicate the need, purposefulness and orderliness of this work, the growing importance of its role and significance in adolescence, its significance during the period of self-isolation and blended learning in a distance learning format, as well as the need for its staged organization by distinguishing the adaptation, manifestation, actualization and individualization stages.

\section{References}

1. N.G. Shilo, Sib. Pedag. J. 1, 16 (2021)

2. M.V. Voropaev, A.S. Anichkina, Sib. Pedag. J. 1, 10 (2020)

3. J. Brody, J. Vissa, J. Weathers, J. Res. Leadership Edu. 5(14), 6 (2010)

4. E. Gable, Tsifrovaya transformatsiya shkolnogo obrazovaniya. Mezhdunarodnyi opyt, trendy, globalnye rekomendatsii obrazovaniya [Digital transformation of school education. International experience, trends, global education recommendations] (NRU HSE, Moscow, 2019)

5. Ch. Hayhurst, How Do Teachers Make Hands-On Classes Work Online? With Tech and Innovation. Accessed on: July 22, 2021. [Online]. Available:

https://edtechmagazine.com/k12/article/2020/10/how-do-teachers-make-hands-classeswork-online-tech-and-innovation

6. V.I. Petrishche, T.P. Grass, M.A. Mashukov, Sib. Pedag. J. 1, 93 (2021)

7. L.A. Stepanova, Stanovlenie traditsii otechestvennogo pedagogicheskogo obrazovaniya v kulturno-istoricheskom kontekste Rossii kontsa XIX-XX veka [Formation of the tradition of domestic pedagogical education in the cultural-historical context of Russia at the end of the 19-20 $0^{\text {th }}$ centuries] (RSSU, Moscow, 2009)

8. M.I. Aldoshina, Edu. Soc. 3(62), 113 (2010)

9. Z.I. Ravkin (ed.), Problemy obrazovaniya i vospitaniya v kontekste gumanisticheskoi paradigmy pedagogiki (konets XIX v. - 90-e gg. XX v.) [Problems of education and upbringing in the context of the humanistic paradigm of pedagogy (late $19^{\text {th }}$ century 90s of the $20^{\text {th }}$ century)] (Moscow, 2000)

10. A.N. Shevelev, Psy. Pedag. Search 2, 26 (2015)

11. E.E. Solovieva, S.I. Popova, Bul. Saint Tikhon's Orthodox Univ. Human. Ser.: Pedag. 
Psy. 58, 22 (2020)

12. I.V. Egorov, Bul. Saint Tikhon's Orthodox Univ. Human. Ser.: Pedag. Psy. 52, 114-115 (2019) 